\title{
What Brussels should do for research
}

The new member of the European Commission with responsibility for research, Professor Antonio Ruberti, has taken a sensible step towards a rational definition of what the European Communities should be looking for.

THERE are two ways of interpreting the decision of Professor Antonio Ruberti to seek advice on the European Communities' (EC's) research programme from three 'wise men', who met as a group for the first time last Friday. The generous interpretation is that Ruberti, unlike many of his predecessors in this post in Brussels, is prepared to consult the scientific community on its needs. The other interpretation is that the EC's research programme is in such a mess that only strong-minded people from outside the commission can impart sense to it. Both views are probably correct.

The research directorate at Brussels is also now a more manageable entity. The programmes of applied research in fields such as information technology have been spun off, leaving Ruberti in charge of science proper. (Other directorates have responsibility for the EC's collective interest in climate change, for example.) The chief component of his predecessors' legacy is the fellowship programme called "Human Capital and Mobility", much criticized for being over-lavish and badly administered (see, for example, Lennart Philipson, Nature 360, 102; 1992). No doubt this programme will prompt much that is good, but nobody knows whether it is good value for money or, for that matter, whether it meets Europe's most urgent needs.

The three wise men (François Gros from France, Ilya Prigogine from Belgium and Carlo Rubbia from Italy and CERN) should urge Ruberti to step back from the turmoil of his job so as to form a view of what Europe's science most needs, and how the European Commission could most effectively assist. Of necessity, with a budget only one per cent or so of what European governments themselves spend on research, it is inevitable that the commission's influence can be only marginal. Moreover, there are the strongest reasons why the commission's support for research should not conflict with that from other sources, the European Science Foundation in particular, which is best placed to make the bridges to the East that European research needs.

\section{Quality}

One crying need is to improve the quality and enlarge the quantity of research at universities in member states that now pay conspicuously too little attention to its support. That is the only way in which the participation in research of young men and women from countries such as Greece, Ireland and Portugal will be increased. The objection that this would seem like charitable interference (not always welcome) and that the rich countries would get nothing from it would be easily countered if it were a condition of research support that new projects should usually be collaborations with members of established groups elsewhere, and that participating institutions should be flexible about the appointment of non-nationals to their faculties. The benefits would be a greater volume of research in the short run and, eventually, a greater supply of European scientists. Who could complain at that?

\section{Scale}

At the other end of the spectrum, there are transnational projects of eminent value that national governments or their grant-making agencies are unlikely to support, for financial or administrative reasons. If the $\mathrm{EC}$ had come into being before CERN was created, it would have been a natural sponsor. (Even now, channelling member states' subscriptions through Brussels would be a convenient guard against currency fluctuations, but would not be acceptable until Brussels had shown that it could participate successfully in the management of large projects; the commission has an inclination to keep existing institutions alive in the face of arguments to the contrary.) More recently, the need for a centre to coordinate long baseline observations by radioastronomers cried out for EC support. The commission's still more recent involvement in the Human Genome Project is a case where the right combination of imagination and self-restraint (from the temptation to be dominant) could work wonders, for science and for the commission's reputation in research.

So there is plenty for Ruberti to do, and plenty for his wise men to say. The danger is that none of them can promise that what they set their hands to now will survive the transition from Ruberti to his successor, perhaps as soon as four years from now. In basic science, the commission's reputation has been damaged over the years by the succession of one programme by another, seemingly on whim. The difficulty seems to be constitutional: one commission cannot bind its successors except to provisions of the Treaty of Rome and its amendments. The wise men could do worse than remind Ruberti what he knows already, that almost anything he decides to do will be valuable if there is some assurance that it will last. And nothing he does will improve European science if it is stopped the minute his back is turned. 